\title{
Keefektifan Pembelajaran Daring Fisika SMA berbasis Probing Promting untuk Meningkatkan Keterampilan Berpikir Kritis Peserta Didik
}

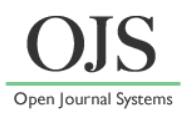

\author{
Irfa' Nindy Adilla*, Budi Jatmiko \\ Jurusan Fisika, FMIPA, Universitas Negeri Surabaya \\ Jl. Ketintang, Surabaya 60231, Indonesia \\ *Email: irfa.17030184014@mhs.unesa.ac.id
}

DOI: https://doi.org/10.33369/pendipa.5.3.426-435

\begin{abstract}
ABSTRAK
Keterampilan berpikir kritis merupakan salah satu kemampuan yang diinginkan dari suatu proses pembelajaran. Penelitian ini memiliki tujuan untuk menganalisis keefektifan pembelajaran daring (dalam jaringan) fisika SMA berbasis Probing Promting untuk meningkatkan keterampilan berpikir kritis peserta didik. Penelitian ini merupakan Pre-Eksperimental Design dengan uji coba One Group Pretest Posttest Design, dengan peserta didik kelas XI MIPA 3 dan XI MIPA 4 SMA Negeri 1 Taman tahun ajaran 2020/2021 sebagai subjek penelitian. Untuk pengumpulan data menggunakan tes dan angket yang diisi peserta didik, dengan cara analisis data menggunakan analisis deskriptif kuantitatif serta interferensial. Hasil penelitian yang dilakukan menunjukkan bahwa pembelajaran daring (dalam jaringan) fisika SMA berbasis Probing Promting efektif untuk meningkatkan keterampilan berpikir kritis peserta didik SMA Negeri 1 Taman. Hal tersebut ditinjau dari (a) Ada peningkatan keterampilan berpikir kritis peserta didik yang signifikan, (b) nilai rerata $n$-gain berkategori tinggi, (c) tidak ada perbedaan peningkatan dari keterampilan berpikir kritis peserta didik kedua kelas. Dengan ini, pembelajaran daring (dalam jaringan) berbasis Probing Promting dapat dijadikan salah satu masukan bagi guru untuk meningkatkan keterampilan berpikir kritis peserta didik.
\end{abstract}

Kata kunci: Keefektifan; Keterampilan berpikir kritis; Probing Promting; Pembelajaran Daring.

\section{ABSTRACT}

Critical thinking skills are one of the capabilities desired from a learning process. This study aims to analyze the effectiveness of online learning (in network) high school physics based on Probing Promting to improve students'critical thinking skills. This research is a Pre-Experimental Design with a One-Group Pretest-Posttest Design trial design, with the research subjects of class XI MIPA 3 and XI MIPA 4 SMA Negeri 1 Taman in the 2020/2021 academic year. For data collection using test and questionnaires given to students, the data analysis techniques used quantitative and interferential descriptive analysis. On the results of the research conducted, it shows that online learning (in network) of high school physics based on Probing Promting is effective for improving students' critical thinking skills. This is viewed from (a) there is an increase in critical thinking skills of student significantly, (b) the average value of n-gain is high, (c) there is no difference the the increase in critical thinking skills of students in two classes. With this, online learning (online) based on Probing Promting can be used as an new inovation for teachers to improve students' critical thinking skills.

Keywords: Effectively; Critical Thinking Skills; Probing Promting; Online Learning.

\section{PENDAHULUAN}

Suatu pendidikan, dimanapun itu pasti tujuan utamanya adalah untuk meningkatkan taraf kualitas hidup sumber daya manusia. Pendidikan dapat dilakukan oleh seluruh kalangan usia, mulai dari bayi yang baru lahir bahkan sampai manusia tersebut menemui ajalnya. Karenakan pendidikan dapat berasal dari berbagai bentuk dan menjadi salah satu kebutuhan sepanjang hidup manusia. Hal ini 
dikemukakan pula oleh (Salam, 2002) bahwa hakikat dari suatu pendidikan adalah usaha yang dilakukan dari dalam maupun dari luar sekolah dengan tujuan mengembangkan kepribadian dan keterampilan manusia dan berlangsung selama hidupnya.

Salah satu keterampilan manusia yang dapat dikembangkan adalah keterampilan berpikir kritis. Kegunaan dari keterampilan berpikir kritis ini salah satunya adalah untuk menyelesaikan suatu permasalahan. Namun menurut Programme for International Student Assesment (2018), Indonesia berada di peringkat 62 dari 71 negara yang tercatat pada kategori Sains. Hal tersebut mengindikasikan bahwa Indonesia masuk dalam kategori Sains yang rendah, serta dapat diartikan pula bahwa keterampilan berpikir kritisnya juga rendah. Hasil tersebut mendukung penelitian yang telah dilakukan oleh (Pratiwi, Hikmawati, \& Gunada, 2019), mereka berpendapat bahwa keterampilan berpikir kritis peserta didik dalam memecahkan masalah kehidupan sehari-hari masih tergolong rendah.

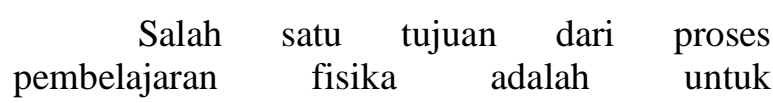
mengembangkan keterampilan peserta didik untuk berpikir, salah satunya merupakan kemampuan berpikir kritis (Yeritia, Wahyudi, \& Rahayu, 2017). Keterampilan berpikir kritis sendiri adalah suatu dasar dari proses pembelajaran (Heong, 2011). Sehingga dengan adanya kemampuan berpikir kritis, peserta didik mampu mengasah pikirannya untuk memilih dan membuat kesimpulan yang menarik serta cerdas. Menurut Handriani (2015), keterampilan berpikir kritis adalah proses kognitif peserta didik yang dilakukan pada saat kegiatan pembelajaran secara mendalam dengan memakai beberapa indikator. Berikut adalah 5 indikator yang dipakai yakni klarifikasi dasar, keputusan dasar, interferensi, penjelasan lebih mendalam, penalaran serta integrasi (Latifa, Verawati, \& Harjono, 2017).

Pada bulan Maret 2020, Indonesia dilanda suatu musibah berupa munculnya Coronavirus Disease - 19 (Covid-19). Dalam rangka menekan pertumbuhan Coronavirus
Disease - 19 (Covid-19) ini, pemerintah menganjurkan masyarakat Indonesia dan bahkan diseluruh dunia untuk stay at home (tetap dirumah), work from home (bekerja dari rumah), dan school from home (sekolah dari rumah) untuk menghindari terjangkit Coronavirus Disease - 19 (Covid-19) (Siahaan, 2020). Hal ini menyebabkan peserta didik, mahasiswa, pekerja, pedagang, dan berbagai sektor masyarakat yang diharuskan keluar rumah, jadinya harus melakukan semua kegiatan yang memerlukan keluar rumah tersebut dijalani dari rumah, atau dalam hal ini bisa disebut sebagai work from home (bekerja dari rumah). Dan dalam menjalankan prosedur pemerintah untuk work from home (bekerja dari rumah) ini, bukan berarti tidak ada suatu kesulitan yang dirasakan masyarat Indonesia. Terutama untuk peserta didik, mereka yang terbiasa belajar tatap muka terpaksa harus melakukan pembelajaran secara daring (dalam jaringan) (Kemendikbud, 2020). Hal ini berdampak besar bagi peserta didik maupun orang tua, karena jika disekolah pasti ada bimbingan dari guru secara langsung dengan penjelasannya yang dapat menuntun peserta didik menemukan jawaban yang dicari, sedangkan ketika belajar daring (dalam jaringan) orang tua lah atau keluarga yang harus mendampingi peserta didik dalam pembelajaran.

Dengan adanya pembelajaran daring (dalam jaringan) yang mempunyai nilai positif dan negatif tersebut, pengajar dituntut untuk membuat rancangan metode belajar yang lebih menarik bagi peserta didik. Terutama bagi pengembangan proses keterampilan berpikir kritis peserta didik. Berdasarkan penelitian yang penulis lakukan di SMAN 1 Taman dengan seorang guru fisika dan peserta didik saat pembelajaran daring (dalam jaringan), bahwa tata cara pembelajaran yang digunakan selama ini adalah metode ceramah, diskusi, dan terkadang ada eksperimen juga. Namun yang lebih dominan adalah metode ceramah, sehingga menjadikan keterampilan berpikir kritis peserta didik kurang menonjol serta kurangnya interaksi antara guru dengan peserta didik. Untuk mengatasi masalah tersebut salah satunya dapat menggunakan metode yang lebih menarik yakni model pembelajaran Probing Promting. Model Probing Promting ini adalah salah satu metode 
pembelajaran yang fokus utamanya adalah peserta didik (Pratiwi, Hikmawati, \& Gunada, 2019). Berdasatkan arti kata secara istilah, Probing adalah suatu pemeriksaan atau penyelidikan sedangkan Promting sendiri adalah menuntun atau bisa juga disebut mendorong. Model pembelajaran Probing Promting adalah suatu model pembelajaran dengan guru yang memberikan beberapa pertanyaan kepada peserta didik yang bersifat menggali pengetahuan awalnya lalu dihubungkan dengan pengetahuan baru yang didapat (Suherman, 2001). Sehingga dari model pembelajaran Probing Promting, diharapkan guru bisa berinteraksi lebih intensif lagi dengan peserta didik.

Keuntungan dari model pembelajaran probing promting ini adalah mendorong peserta didik aktif berpikir, bisa mengulang kembali pelajaran yang lampau dengan dihubungkan dengan materi baru, jika peserta didik kurang faham bisa ditanyakan kembali, dapat memusatkan perhatian peserta didik, dapat mengembangkan keberanian peserta didik dalam keterampilan mengungkapkan pendapat dan menjawab suatu pertanyaan (Megasari, Sundaryono, \& Firdaus, 2018).

Selain memakai model pembelajaran yang menarik bagi peserta didik, perangkat pembelajaran yang disusun oleh guru saat melakukan pembelajaran daring (dalam jaringan) pun juga harus menarik. Dalam melakukan pembelajaran daring (dalam jaringan). Serta saat pembelajaran dapat dibantu dengan beberapa aplikasi video conference seperti zoom dan google meeting. Serta untuk pengumpulan tugasnya dapat melalui apikasi google classroom, google drive, dan email.

Salah satu materi fisika yang dapat mendukung peserta didik dalam melatih keterampilan berpikir kritis adalah materi suhu dan kalor. Pada materi ini terdapat beberapa fenomena alam yang seringkali dijumpai peserta didik dalam kehidupannya. Sehingga dapat memudahkan peserta didik menghubungkan pengalaman awal dan masa lampau dengan pengalaman baru yang diberikan guru melalui pertanyaan-pertanyaan yang diajukan.
Penelitian ini memiliki tujuan untuk mengukur keefektifan pembelajaran daring (dalam jaringan) fisika SMA berbasis model pembelajaran Probing Promting untuk meningkatkan kemampuan berfikir kritis peserta didik SMAN 1 Taman kelas XI MIPA 3 dan XI MIPA 4 sebelum dan sesudah diterapkannya model pembelajaran Probing Promting.

\section{METODE PENELITIAN}

Penelitian yang dilakukan penulis adalah penelitian eksperimen yang dilakukan secara daring (dalam jaringan). Penelitian ini dilakukan kepada peserta didik kelas XI MIPA dari SMA Negeri 1 Taman tahun ajaran 2020/2021 semester gasal. 2 kelas yang mengikuti penelitian ini adalah kelas XI MIPA 3 yang memiliki 36 anggota kelas dan XI MIPA 4 yang memiliki 36 anggota kelas juga.

Dalam penelitian ini memakai model pembelajaran Probing Promting dengan beberapa perangkat pembelajaran berupa silabus, Rencana Pelaksanaan Pembelajaran (RPP), modul, Lembar Kerja Peserta Didik (LKPD), powerpoint (PPT), dan soal yang akan diujikan. Penelitian dilakukan menggunakan aplikasi video conference google meeting dan zoom, serta untuk pengumpulan tugas menggunakan aplikasi google classroom. Selain perangkat pembelajaran, ada pula beberapa instrumen yang mendukung keterlaksanaan penelitian yakni lembar validasi perangkat pembelajaran, soal tes keterampilan berpikir kritis, angket respon untuk peserta didik, dan angket keterlaksanaan pembelajaran.

Penelitian ini memakai metode penelitian Pre-Experimental Design serta menggunakan uji coba One Group Pretest Posttest Design berikut (Sugiyono, 2014) :

\section{$\mathbf{O}_{1} \mathrm{X} \mathrm{O}_{2}$}

Keterangan :

$\mathrm{O}_{1} \quad=$ Tes yang dilakukan kepada peserta didik dari materi pembelajaran yang diujikan sebelum adanya perlakuan atau dalam kata lain disebut pretest. 
$\mathrm{X}=$ Pemberian perlakuan kepada peserta didik saat melakukan proses pembelajaran memakai model pembelajaran probing promting.

$\mathrm{O}_{2} \quad=$ Tes yang dilakukan kepada peserta didik dari materi pembelajaran yang diujikan setelah adanya perlakuan atau dalam kata lain disebut posttest.

Dalam hal pengumpulan data menggunakan teknik yang akurat, relevan, dan disesuaikan dengan tujuan pembelajaran. Teknik tersebut adalah dengan memberikan tes dan angket respon kepada peserta didik, serta melakukan penelitian saat berlangsungnya proses belajar mengajar. Berikut adalah beberapa analisis hasil penelitian serta uji coba proses pembelajaran yang dilakukan untuk penelitian :

(1) Analisis Validitas Perangkat Pembelajaran

Berikut adalah kriteria skor ratarata tiap aspek untuk mengukur kevalidan perangkat pembelajaran (Ratumanan \& Laurens, 2006):

Tabel 1. Kriteria skor validitas perangkat pembelajaran

\begin{tabular}{|c|c|}
\hline Nilai & Keterangan \\
\hline $3,5 \leq \mathrm{Y} \leq 4,0$ & Sangat Baik / Sangat Valid \\
\hline $2,5 \leq \mathrm{Y} \leq 3,5$ & Baik / Valid \\
\hline $1,5 \leq \mathrm{Y} \leq 2,5$ & $\begin{array}{c}\text { Kurang Baik / Kurang } \\
\text { Valid }\end{array}$ \\
\hline $0 \leq \mathrm{Y} \leq 1,5$ & Tidak Baik / Tidak Valid \\
\hline
\end{tabular}

(2) Analisis Keterampilan Berpikir Kritis Bagi Peserta Didik

Analisis ini dilakukan untuk mengetahui apakah peserta didik sudah menguasai keterampilan ini atau belum. Analisis ini dilakukan secara diskriptif kuantitatif menggunkan persamaan :

$P=\frac{\Sigma \text { skor yang diperoleh }}{\Sigma \text { skor maksimum }} \times 100 \%$

Peserta didik dapat dinyatakan lulus/tuntas dengan hasil keterampilan berpikir kritis yang memenuhi Kriteria Ketuntasan Minimal (KKM) yang telah ditentukan sekolah SMA Negeri 1 Taman, yakni sebesar 80 .
Dari data pretest dan posttest peserta didik, kemudian dilakukan analisis $n$-gain. Analisis ini bertujuan untuk mengetahui perbedaan pengetahuan fisika sebelum dan sesudah peserta didik diberi perlakuan.

$$
<g>=\frac{s_{\text {post }}-s_{\text {pre }}}{s_{\text {max }}-S_{\text {pre }}}
$$

Dengan :

$$
\begin{array}{ll}
\langle\mathrm{g}\rangle & =\text { nilai gain } \\
\mathrm{S}_{\text {post }} & =\text { nilai posttest } \\
\mathrm{S}_{\text {pre }} & =\text { nilai pretest } \\
\mathrm{S}_{\max } & =\text { nilai maksimum }
\end{array}
$$

Kemudian hasil dari perhitungan tersebut diubah mengikuti kriteria n-gain (Hake, 1999) berikut:

Tabel 2. Kriteria $n$-gain

\begin{tabular}{|c|c|}
\hline Nilai & Kriteria $\boldsymbol{n}$-gain \\
\hline$n$-gain $<0,3$ & Rendah \\
\hline $0,3 \leq n$-gain $\leq 0,7$ & Sedang \\
\hline $0,7<$-gain & Tinggi \\
\hline
\end{tabular}

Setelah itu melakukan analisis statistik pada keterampilan berpikir kritis peserta didik setelah diberikan perlakuan memakai model pembelajaran Probing Promting. Untuk menguji perbedaan hasil dari nilai pretest dan posttest peserta didik kelas XI MIPA 3 dan XI MIPA 4, menggunakan metode statistik parametrik dengan taraf signifikasi $\alpha=0,05$ (2-tailed) sebagai berikut :

a) Perbedaan Keterampilan Berpikir Kritis Awal.

Untuk mengetahui perbedaan dari pemahaman awal peserta didik setiap kelas mengenai kemampuan berpikir kritisnya, dapat menggunakan uji $t$-independent pada data pretest dan posttest dengan hipotesis sebagai berikut:

$\mathrm{H}_{0}$ : Tidak adanya perbedaan keterampilan berpikir kritis awal peserta didik kedua kelas.

$\mathrm{H}_{1}$ : Ada perbedaan keterampilan berpikir kritis awal peserta didik kedua kelas.

Berikut adalah kriteria dalam menolak atau menerima $\mathrm{H}_{0}$ berdasarkan 
dari $t_{\text {hitung }}$ pada pengujian hipotesis menurut Sugiyono (2014) :

Ketika $\mathrm{t}_{\text {hitung }}>\mathrm{t}_{\text {tabel }}, \mathrm{H}_{0}$ ditolak.

Ketika $\mathrm{t}_{\text {hitung }}<\mathrm{t}_{\text {tabel }}, \mathrm{H}_{0}$ diterima.

b) Peningkatan Keterampilan Berpikir Kritis.

Untuk mengetahui peningkatan dari pemahaman peserta didik setiap kelas mengenai kemampuan berpikir kritisnya, dapat menggunakan uji $t$ berpasangan pada data pretest dan posttest dengan hipotesis sebagai berikut :

$\mathrm{H}_{0}$ : Tidak adanya peningkatan keterampilan berpikir kritis peserta didik kedua kelas.

$\mathrm{H}_{1}$ : Ada peningkatan keterampilan berpikir kritis peserta didik kedua kelas.

Berikut adalah kriteria dalam menolak atau menerima $\mathrm{H}_{0}$ berdasarkan dari $t_{\text {hitung }}$ pada pengujian hipotesis menurut Sugiyono (2014) :

Ketika $t_{\text {hitung }}>\mathrm{t}_{\text {tabel }}, \mathrm{H}_{0}$ ditolak.

Ketika $\mathrm{t}_{\text {hitung }}<\mathrm{t}_{\text {tabel }}, \mathrm{H}_{0}$ diterima.

c) Perbedaan Peningkatan Keterampilan Berpikir Kritis.

Untuk mengetahui perbedaan peningkatan dari pemahaman peserta didik setiap kelas mengenai keterampilan berpikir kritisnya, dapat menggunakan uji t-independent pada data $n$-gain dengan hipotesis sebagai berikut :

$\mathrm{H}_{0}$ : Tidak adanya perbedaan peningkatan keterampilan berpikir kritis peserta didik kedua kelas.

$\mathrm{H}_{1}$ : Ada perbedaan peningkatan keterampilan berpikir kritis peserta didik kedua kelas.

Berikut adalah kriteria dalam menolak atau menerima $\mathrm{H}_{0}$ berdasarkan dari $t_{\text {hitung }}$ pada pengujian hipotesis menurut Sugiyono (2014) :

Ketika $t_{\text {hitung }}>t_{\text {tabel }}$, maka $\mathrm{H}_{0}$ ditolak.

Ketika $\mathrm{t}_{\text {hitung }}<\mathrm{t}_{\text {tabel }}$, maka $\mathrm{H}_{0}$ diterima.

\section{HASIL DAN PEMBAHASAN}

Hasil data yang tertera pada penelitian ini adalah data yang penulis peroleh dari penelitian terhadap peserta didik SMA Negeri 1 Taman kelas XI MIPA 3 dan XI MIPA, dengan menggunakan model pembelajaran Probing Promting secara daring (dalam jaringan).
Sebelum melakukan penelitian melalui proses pembelajaran secara daring (dalam jaringan), perangkat pembelajaran yang digunakan telah melalui proses validasi oleh 2 orang dosen validator. Hasil dari validasi terhadap perangkat pembelajaran menggunakan model Probing Promting dinyatakan valid dan dapat digunakan dalam proses pembelajarn fisika guna meningkatkan proses keterampilan berpikir kritis peserta didik.

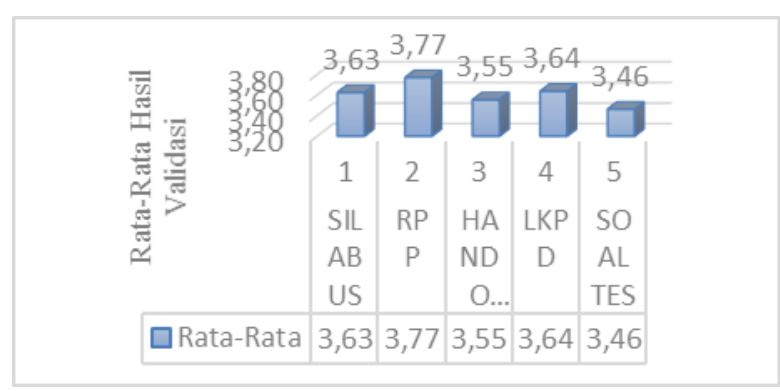

Gambar 1. Hasil Validasi Perangkat Pembelajaran Fisika

Dari tabel diatas, dapat dilihat bahwa rata-rata hasil validasi perangkat pembelajaran silabus, RPP, Handout, serta LKPD yang penulis dapat berkisar antara 3,5-4,0. Yang dapat diartikan bahwa perangkat pembelajaran silabus, RPP, Handout, serta LKPD penulis berada pada kategori sangat baik/sangat valid untuk dapat digunakan dalam proses pembelajaran. Sedangkan untuk soal pretest dan posttest, hasil validasi yang penulis dapat adalah 3,46. Yang berarti termasuk dalam kategori baik/valid. Sehingga berdasarkan hasil tersebut, perangkat pembelajaran yang penulis gunakan dinyatakan layak untuk digunakan.

Proses pembelajaran fisika daring (dalam jaringan) dengan berbasis model pembelajaran Probing Promting dapat dikatakan efektif apabila dapat terlaksana dengan baik dan terstruktur. Berdasarkan hasil dari analisis keterlaksanaan Rencana Pelaksanaan Pembelajaran (RPP), didapatkan bahwa fase-fase dalam kegiatan pembelajaran yang ada pada RPP telah terlaksana dengan nilai rata-rata 3,52 dan 3,84 serta berkategori baik dengan nilai reliabilitas $93,33 \%$.

Keterlaksanaan RPP yang baik adalah yang menunjukkan bahwa guru dapat menuntun 
peserta didik dalam menjalankan fase-fase dalam kegiatan pembelajaran sesuai dengan model Probing Promting. Selain itu, dapat pula dilihat dari peserta didik yang bisa menggabungkan maupun memodifikasi pengetahuan awalnya dengan pengetahuan baru yang didapat mengenai materi suhu dan kalor. Sehingga dari hal tersebut guru dapat menuntun peserta didik menemukan jawaban dari permasalahan yang ada melalui pertanyaan-pertanyaan yang diberikan. Menurut penelitian yang dilakukan oleh (Kariani, Putra, \& Ardana, 2014), menyatakan bahwa model Probing Promting memberi kesempatan peserta didik agar dapat bereksplorasi, menggabungkan, serta menganalisis data secara lebih lengkap dan runtut sesuai dengan permasalahan yang ada.

Sebelum proses pembelajaran berbasis model Probing Promting berlangsung, peserta didik sebelumnya diberi tes awal berupa pretest guna menyelidiki kemampuan berpikir kritis peserta didik sebelum proses pembelajaran Probing Promting dilangsungkan. Kemudian setelah dilakukan proses pembelajaran berbasis model Probing Promting, peserta didik juga diberi tes akhir berupa posttest guna menyelidiki keterampilan berpikir kritis peserta didik setelah dilakukan perlakuan. Dari nilai pretest dan posttest yang didapat, kemudian akan dibandingkan guna mengukur perbedaan sebelum dan setelah dilakukan proses pembelajaran berbasis Probing Promting. Selanjutnya nilai yang didapat dilakukan analisis deskriptif, kemudian dilanjut dengan perhitungan $n$-gain guna menyelidiki ada atau tidaknya peningkatan keterampilan berpikir kritis peserta didik.

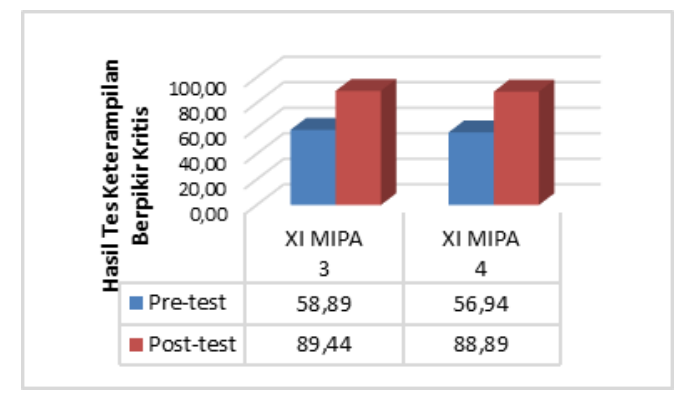

Gambar 2. Hasil Rata-Rata Nilai Keterampilan Berpikir Kritis Peserta Didik Kelas XI MIPA 3 dan XI MIPA 4.
Berdasarkan grafik tersebut, didapatkan bahwa sebelum dilakukan proses pembelajaran berbasis Probing Promting, keterampilan berpikir kritis peserta didik berada dibawah KKM dengan rerata nialai pretest dari kelas XI MIPA 3 adalah 58,89 dan kelas XI MIPA 4 dengan nilai 56,94. Namun, setelah dilakukan proses pembelajaran berbasis Probing Promting, keterampilan berpikir kritis peserta didik mengalami peningkatan dengan nilai posttest kelas XI MIPA 3 adalah 89,44 dan kelas XI MIPA 4 dengan nilai 88,89 . Serta dengan keseluruhan jumlah peserta didik adalah tuntas.

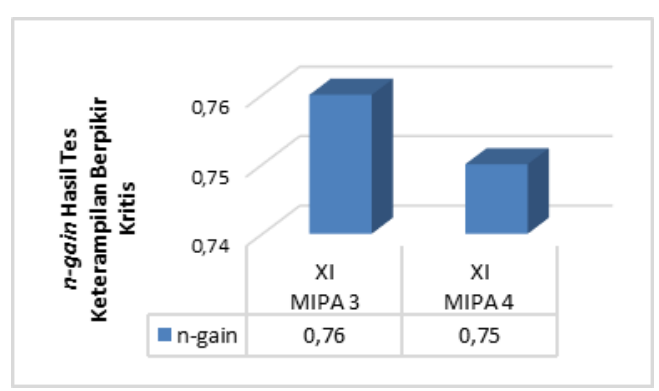

Gambar 3. Hasil Rerata Nilai $n$-gain Kelas XI MIPA 3 dan XI MIPA 4

Dari tabel diatas, dapat diketahui bahwa hasil rerata nilai n-gain yang didapat adalah 0,76 dan 0,75 . Sehingga menunjukkan bahwa kedua kelas memiliki hasil kategori tinggi.

Berikut merupakan beberapa uji kemampuan berpikir kritis peserta didik :

1) Perbedaan Keterampilan Berpikir Kritis Awal.

Uji perbedaan, diperoleh dari hasil data soal pretest yang diberikan kepada peserta didik. Uji perbedaan ini memakai uji $t$ independent dengan taraf signifikasi $\alpha=0,05$ (2-tailed). Berikut adalah hasilnya :

Tabel 4. Hasil uji t-independent pretest

\begin{tabular}{|c|c|c|c|c|c|}
\hline Sampel & $\begin{array}{c}\text { Mea } \\
\text { n }\end{array}$ & $\begin{array}{c}\text { Std. } \\
\text { Devia } \\
\text { tion }\end{array}$ & $\begin{array}{c}\mathbf{t}_{\text {hitun }} \\
\mathrm{g}\end{array}$ & $\mathbf{t}_{\text {tabel }}$ & $\begin{array}{c}\text { Kesi } \\
\text { mpul } \\
\text { an }\end{array}$ \\
\hline XI & 58,8 & 67,30 & \multirow{3}{*}{$\begin{array}{c}1,00 \\
4\end{array}$} & \multirow{3}{*}{$\begin{array}{c}2,03 \\
0\end{array}$} & \multirow{3}{*}{$\begin{array}{c}\mathrm{H}_{0} \\
\text { diteri } \\
\text { ma }\end{array}$} \\
\hline MIPA 3 & 99 & 2 & & & \\
\hline $\begin{array}{c}\text { XI } \\
\text { MIPA } 4\end{array}$ & $\begin{array}{c}56,9 \\
44\end{array}$ & $\begin{array}{c}67,53 \\
9\end{array}$ & & & \\
\hline
\end{tabular}


Dari tabel tersebut, dapat diketahui bahwa nilai $t_{\text {hitung }}<\mathrm{t}_{\text {tabel }}$, maka dapat diartikan bahwa $\mathrm{H}_{0}$ diterima.

2) Peningkatan Keterampilan Berpikir Kritis.

Uji peningkatan, diperoleh dari hasil data soal pretest dan posttest yang diberikan kepada peserta didik. Untuk uji peningkatan ini memakai uji $t$ berpasangan dengan taraf signifikasi $\alpha=0,05$ (2-tailed). Berikut adalah hasilnya :

Tabel 5. Hasil uji $t$ berpasangan pretest dan

\begin{tabular}{|c|c|c|c|c|c|c|c|}
\hline \multicolumn{8}{|c|}{ posttest } \\
\hline \multicolumn{2}{|c|}{ Sampel } & Mea & Varien & $\begin{array}{l}\text { Pea } \\
\text { rson } \\
\text { Cor }\end{array}$ & $\mathbf{t}_{\text {hitun }}$ & $t_{\text {tabe }}$ & $\begin{array}{l}\text { Kesi } \\
\text { mpul }\end{array}$ \\
\hline \multirow{2}{*}{$\begin{array}{c}\text { XI } \\
\text { MIP } \\
\text { A } 3\end{array}$} & $\begin{array}{c}\text { Pret } \\
\text { est }\end{array}$ & $\begin{array}{c}58,8 \\
89\end{array}$ & $\begin{array}{c}67,2 \\
01\end{array}$ & 0,71 & 31,4 & \multirow{4}{*}{$\begin{array}{c}2,0 \\
30\end{array}$} & \multirow{4}{*}{$\begin{array}{c}\mathrm{H}_{0} \\
\text { ditol } \\
\text { ak }\end{array}$} \\
\hline & $\begin{array}{l}\text { Post } \\
\text { test }\end{array}$ & $\begin{array}{c}89,4 \\
44\end{array}$ & $\begin{array}{c}45,3 \\
96\end{array}$ & 2 & 56 & & \\
\hline \multirow{2}{*}{$\begin{array}{c}\text { XI } \\
\text { MIP } \\
\text { A } 4\end{array}$} & $\begin{array}{l}\text { Pret } \\
\text { est }\end{array}$ & $\begin{array}{c}56,9 \\
44\end{array}$ & $\begin{array}{c}67,5 \\
39\end{array}$ & \multirow{2}{*}{$\begin{array}{c}0,49 \\
9\end{array}$} & \multirow{2}{*}{$\begin{array}{c}23,3 \\
22\end{array}$} & & \\
\hline & $\begin{array}{c}\text { postt } \\
\text { est }\end{array}$ & $\begin{array}{c}88,8 \\
89\end{array}$ & $\begin{array}{c}67,3 \\
01\end{array}$ & & & & \\
\hline
\end{tabular}

Dari tabel tersebut, dapat diketahui bahwa nilai $t_{\text {hitung }}>t_{\text {tabel }}$, maka dapat diartikan bahwa $\mathrm{H}_{0}$ ditolak.

3) Perbedaan Peningkatan Berpikir Kritis.

Uji perbedaan peningkatan, diperoleh dari data $n$-gain keterampilan berpikir kritis peserta didik kedua kelas. Untuk uji perbedaan peningkatan ini memakai uji $t$ independent dengan taraf signifikasi $\alpha=0,05$ (2-tailed). Berikut adalah hasilnya :

Tabel 6. Hasil uji $t$-independent data $n$-gain

\begin{tabular}{|c|c|c|c|c|c|}
\hline $\begin{array}{c}\text { Samp } \\
\text { el }\end{array}$ & $\begin{array}{c}\text { Mea } \\
\mathbf{n}\end{array}$ & $\begin{array}{c}\text { Std. } \\
\text { Deviation }\end{array}$ & $\begin{array}{c}\mathbf{t}_{\text {hitun }} \\
\mathbf{g}\end{array}$ & $\mathbf{t}_{\text {tabel }}$ & $\begin{array}{l}\text { Kesimpul } \\
\text { an }\end{array}$ \\
\hline $\begin{array}{c}\text { XI } \\
\text { MIPA }\end{array}$ & 0,76 & 0,021 & \multirow{2}{*}{$\begin{array}{c}0,08 \\
4\end{array}$} & \multirow{2}{*}{$\begin{array}{c}2,03 \\
0\end{array}$} & \multirow{2}{*}{$\begin{array}{c}\mathrm{H}_{0} \\
\text { diterima }\end{array}$} \\
\hline $\begin{array}{c}\text { XI } \\
\text { MIPA } \\
4\end{array}$ & 0,75 & 0,033 & & & \\
\hline
\end{tabular}

Dari tabel tersebut, dapat diketahui bahwa nilai $t_{\text {hitung }}<\mathrm{t}_{\text {tabel }}$, maka dapat diartikan bahwa $\mathrm{H}_{0}$ diterima.

Berdasarkan perhitungan data n-gain dari pretest dan posttest peserta didik yang telah dirata-rata. Hasil tersebut menyatakan bahwa rata-rata n-gain mencapai kategori tinggi, dengan skor pada kelas XI MIPA 3 adalah 0,76 dan XI MIPA 4 adalah 0,75. Yang mana ketika n-gain menunjukkan kategori tinggi, berarti dapat dinyatakan bahwa model pembelajaran berbasis Probing Promting pada materi suhu dan kalor yang dilakukan secara daring (dalam jaringan) dapat meningkatkan keterampilan berpikir kritis peserta didik secara signifikan.

Penggunaan model pembelajaran berbasis Probing Promting ini mendukung seluruh peserta didik untuk lebih aktif mengikuti pembelajaran. Selain itu, dengan memakai model Probing Promting dapat memberikan kebebasan untuk peserta didik mengembangkan pembelajaran, sehingga pembelajaran yang berlangsung dapat berpusat pada peserta didik (student centered). Sedangkan guru hanya berperan sebagai motivator dan fasilitator. Model Probing Promting ini erat kaitannya dengan memberikan pertanyaan-pertanyaan yang bersifat menuntun peserta didik dalam penyelesaian masalah dengan menghubungkan pengetahuan awal dan pengetahuan baru yang didapatkan.

Walaupun proses pembelajaran berlangsung secara daring (dalam jaringan), tidak menyurutkan antusias peserta didik untuk dapat menjawab setiap pertanyaan yang diutarakan oleh guru. Bahkan peserta didik saling berebutan saat menjawab rangkaian pertanyaan yang diberikan guru. Sebelum diberikan pertanyaan, guru memberikan gambar maupun video berupa permasalahan yang berhubungkan dengan materi suhu dan kalor. Kemudian baru diberikan pertanyaanpertanyaan untuk menggiring peserta didik dalam menjawab permasalahan tersebut. Ketika ada peserta didik yang belum bisa menjawab permasalahan yang diberikan, maka guru akan memberikan pertanyaan lanjutan sampai peserta didik tersebut dapat 
menjawab permasalahan yang diberikan. Setelah peserta didik yang ditunjuk dapat menjawab permasalahan yang diberikan, maka akan dilemparkan kepada peserta didik lain untuk mengetahui apakah peserta didik yang lain mengikuti proses pembelajaran atau tidak. Hal ini diulangi kembali kepada peserta didik yang lain dengan permasalahan yang berbeda, agar peserta didik lain dapat dipastikan mengikuti pembelajaran secara optimal.

Untuk menganalisis keefektifan proses pembelajaran fisika berbasis model Probing Promting guna meningkatkan keterampilan berpikir kritis peserta didik, dapat menggunakan analisis statistik interferensial. Data yang didapatkan dari penelitian, kemudian dianalisis statistik memakai analisis statistik interferensial parametrik (uji $t$ independent dan uji $t$ berpasangan).

Dari hasil uji t-independent pretest, maka diketahui pada kedua kelas memiliki nilai $t_{\text {hitung }}<t_{\text {tabel }}$, sehingga $\mathrm{H}_{0}$ diterima. Dengan $\mathrm{H}_{0}$ diterima adalah tidak adanya perbedaan keterampilan berpikir kritis awal peserta didik dari kedua kelas sebelum diterapkannya proses pembelajaran berbasis Probing Promting. Atau dapat disebut bahwa keterampilan berpikir pada kedua kelas sebelum diterapkan perlakuan adalah sama. Dengan nilai pretest pada XI MIPA 3 adalah 58,899 dan pada XI MIPA 4 adalah 56,944.

Dari hasil uji $t$ berpasangan pretest dan posttest, maka diketahui pada kedua kelas memiliki nilai $t_{\text {hitung }}>t_{\text {tabel}}$, sehingga $H_{0}$ ditolak. Dengan $\mathrm{H}_{0}$ ditolak adalah adanya peningkatan keterampilan berpikir kritis peserta didik dari kedua kelas setelah diterapkannya proses pembelajaran berbasis Probing Promting. Hal ini menjelaskan bahwa terjadi peningkatan keterampilan berpikir setelah diberi perlakuan, dengan nilai posttest XI IPA 3 adalah 89,444 dan XI MIPA 4 adalah 88,889 .

Untuk menyelidiki ada atau tidaknya perbedaan peningkatan keterampilan berpikir kritis peserta didik, dilakukan perhitungan $n$ gain menggunakan uji t-independent. Dan hasilnya adalah pada kedua kelas memiliki nilai $t_{\text {hitung }}<t_{\text {tabel }}$, sehingga dapat diartikan bahwa $\mathrm{H}_{0}$ diterima. Dengan $\mathrm{H}_{0}$ diterima adalah tidak ada perbedaan peningkatan keterampilan berpikir kritis peserta didik dari kedua kelas. Hal tersebut dikarenakan guru telah melakukan proses pembelajaran berbasis Probing Promting secara maksimal pada kedua kelas. Sehingga kedua kelas sama-sama memiliki peningkatan keterampilan berpikir kritis dengan kategori $n$-gain yang tinggi.

Nilai rerata keterampilan berpikir kritis peserta didik pada kedua kelas adalah 89,17, yang berarti berkategori baik. Hasil keterampilan berpikir peserta didik yang berkategori baik tersebut, dikarenakan peserta didik melakukan proses pembelajaran secara maksimal dengan guru sebagai motivator dan fasilitatornya. Walaupun proses pembelajaran dilakukan secara daring (dalam jaringan), namun peserta didik tetap aktif saat pembelajaran berlangsung dan bahkan sangat antusias dalam menjalankan pembelajaran. Dari guru memberikan permasalahan melalui gambar maupun video. Kemudian peserta didik diberikan pertanyaan dan dapat menyelesaikan permasalahan yang ada. Namun jika belum dapat menjawab permasalahan, maka guru akan terus memberikan pertanyaan yang sifatnya menggiring peserta didik agar dapat menyelesaikan permasalahan. Semua kegiatan pembelajaran dilaksanakan peserta didik dengan baik dan sesuai dengan sintaks pada model pembelajaran Probing Promting. Serta dalam pengumpulan tugas, peserta didik dibantu dengan adanya aplikasi google classroom. Sehingga guru pun dapat memberikan feedback berupa nilai kepada peserta didik lebih mudah dan langsung dapat diketahui peserta didik.

Berdasarkan hasil tes keterampilan yang telah diujikan, peserta didik dianggap telah mampu melatihkan keterampilan berpikir kritisnya. Namun, peserta didik juga masih memerlukan bimbingan dan latihan agar tetap bisa memecahkan masalah melalui keterampilan berpikir kritis atau bahkan meningkatkan kemampuan berpikir kritisnya. Terutama untuk permasalahan sehari-hari yang memerlukan konsep fisika. Walaupun dengan pembelajaran daring (dalam jaringan), peserta didik dan guru dapat dibantu dengan 
aplikasi video conference seperti zoom maupun google meeting.

Jadi dari hasil analisis statistik interferensial yang telah dilakukan, dapat disimpulkan bahwa pembelajaran daring (dalam jaringan) fisika SMA berbasis Probing Promting pada materi suhu dan kalor mampu menunjukkan keefektifannya dalam meningkatkan keterampilan berpikir kritis peserta didik. (Pratiwi, Hikmawati, \& Gunada, 2019) menyebutkan hal yang sama dalam penelitiannya mengenai pengaruh model pembelajaran Probing Promting yang efektif meningkatkan hasil belajar dan kemampuan berpikir kritis peserta didik dengan berbantuan video. Pada penelitian yang dilakukan (Hidayatullah, Raga, \& Mahadewi, 2014), juga menyebautkan bahwa model pembelajaran Probing Promting berpengaruh terhadap kemampuan berpikir kritis IPA peserta didik. Selain itu, sesuai pula dengan penelitian yang dilakukan (Susanti \& Elsa, 2017) mengenai penerapan model pembelajaran Probing Promting untuk meningkatkan kemampuan berpikir kritis matematis siswa yang menunjukkan bahwa model pembelajaran Probing Promting mampu meningkatkan keterampilan berpikir kritis matematis siswa. Sehingga model pembelajaran Probing Promting ini, dapat dijadikan masukan bagi guru untuk membantu meningkatkan keterampilan berpikir kritis peserta didik.

\section{KESIMPULAN}

Dari hasil analisis data yang telah dilakukan, dapat disimpulkan bahwa pembelajaran daring (dalam jaringan) fisika SMA berbasis Probing Promting efektif untuk meningkatkan keterampilan berpikir kritis peserta didik kelas XI MIPA 3 dan XI MIPA 4 SMA Negeri 1 Taman. Hal ini ditinjau dari adanya peningkatan nilai keterampilan berpikir kritis peserta didik yang signifikan, dengan rerata nilai $n$-gain untuk XI MIPA 3 yakni 0,76 dan XI MIPA 4 yakni 0,75 yang berkategori tinggi, serta tidak adanya perbedaan peningkatan keterampilan berpikir kritis peserta didik kelas XI MIPA 3 maupun kelas XI MIPA 4 SMA Negeri 1 Taman.

\section{DAFTAR PUSTAKA}

Heong, Y. M., Yunos, J. M., Hassan, R. B., Othman, W. B., Kiong, T. T. (2011). The Perception of The Level of Higher Order Thinking Skills among Technical Education Students. International Conference on Social Science and Humanity journal, 281285.

Hidayatullah, A. P., Raga, G., \& Mahadewi, P. L. (2014). Pengaruh Model ProbingPromting terhadap Kemampuan Berpikir Kritis Siswa pada Mata Pelajaran IPA Kelas V. e-Journal MIMBAR PGSD Universitas Pendidikan Ganesha.

Kariani, Putra, S., \& Ardana. (2014). Model Problem Based Learning Menggunakan Metode Probing-Promting Berpengaruh Terhadap Hasil Belajar IPA Siswa. Jurnal Mimbar PGSD Universitas Pendidikan Ganesha.

Kemendikbud. (2020). Surat Edaran No 15 Tahun 2020 Tentang Pedoman Penyelenggaraan Belajar dari Rumah dalam Masa Darurat Penyebaran Corona Virus Disease (Covid 19).

Latifa, B. R., Verawati, N. N., \& Harjono, A. (2017). Pengaruh Model Learning Cycle 5E (Engage, Explore, Explain, Eleboration, \& Evaluate) terhadap Kemampuan Berpikir Kritis Peserta Didik Kelas X MAN 1 Mataram. Jurnal Pendidikan Fisika dan Teknologi, 61-67.

Megasari, Sundaryono, A., \& Firdaus, M. (2018). Pembelajaran probing promting untuk meningkatkan berpikir kritis siswa anggota kelompok ilmiah remaja. PENDIPA Jornal of Science Education, 163-169.

Pratiwi, R., Hikmawati, \& Gunada, I. (2019). Pengaruh Model Pembelajaran Probing Promting Berbantuan Video Terhadap Hasil Belajar dan Kemampuan Berpikir Kritis Peserta Didik. Jurnal Pendidikan Fisika dan Teknologi, 213-220. 
Ratumanan, G. T., \& Laurens. (2011). Evaluasi Hasil Belajar pada Tingkat Satuan Pendidikan. Surabaya: Unesa University Press.

Salam, B. (2002). Pengantar pendagogik (dasardasar ilmu mendidik). Jakarta: PT Rineka Cipta.

Siahaan. (2020). Dampak Pandemi Covid-19 Terhadap Dunia Pendidikan. Jurnal Kajian Ilmiah, 1(1), 73-80.

Suherman. (2001). Pembelajaran Probing Promting. Retrieved Februari 2021, from Math Face: http://ayuface.wordpresss.com
Susanti, \& Elsa. (2017). Penerapan Model Pembelajaran Probing Promting Untuk Meningkatkan Kemampuan Berpikir Krritis Matematis Siswa Kelas XI IPA MAN 1 Bengkulu. Jurnal Pendidikan Matematika Raflesia, 96-107.

Yeritia, S., Wahyudi, \& Rahayu, S. (2017). Pengaruh Model Pembelajaran Inkuiri Terbimbing Terhadap Penguasaan Konsep dan Kemampuan Berpikir Kritis Fisika Peserta Didik Kelas X SMAN 1 Kuripan Tahun Ajaran 2017/2018. Jurnal Pendidikan Fisika dan Teknologi, 181-187. 